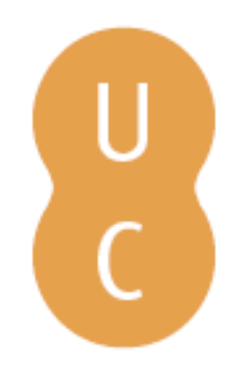

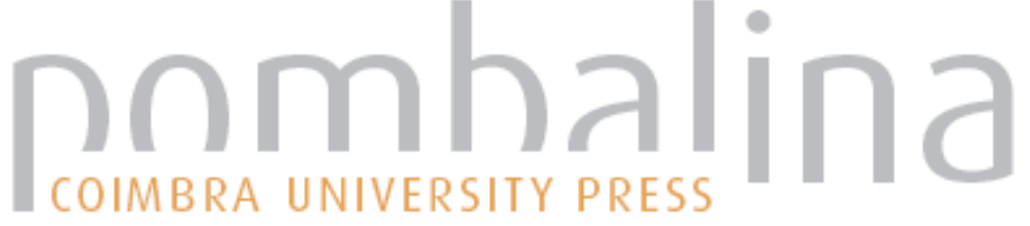

\section{Democratic culture, public opinion and punditry in Portugal}

\author{
Autor(es): $\quad$ Figueiras, Rita
}

Publicado por: Imprensa da Universidade de Coimbra

URL

persistente:

URI:http://hdl.handle.net/10316.2/35144

DOI:

DOI:http://dx.doi.org/10.14195/978-989-26-0917-1_3

Accessed : $\quad$ 26-Apr-2023 10:42:17

A navegação consulta e descarregamento dos títulos inseridos nas Bibliotecas Digitais UC Digitalis, UC Pombalina e UC Impactum, pressupõem a aceitação plena e sem reservas dos Termos e Condições de Uso destas Bibliotecas Digitais, disponíveis em https://digitalis.uc.pt/pt-pt/termos.

Conforme exposto nos referidos Termos e Condições de Uso, o descarregamento de títulos de acesso restrito requer uma licença válida de autorização devendo o utilizador aceder ao(s) documento(s) a partir de um endereço de IP da instituição detentora da supramencionada licença.

Ao utilizador é apenas permitido o descarregamento para uso pessoal, pelo que o emprego do(s) título(s) descarregado(s) para outro fim, designadamente comercial, carece de autorização do respetivo autor ou editor da obra.

Na medida em que todas as obras da UC Digitalis se encontram protegidas pelo Código do Direito de Autor e Direitos Conexos e demais legislação aplicável, toda a cópia, parcial ou total, deste documento, nos casos em que é legalmente admitida, deverá conter ou fazer-se acompanhar por este aviso.

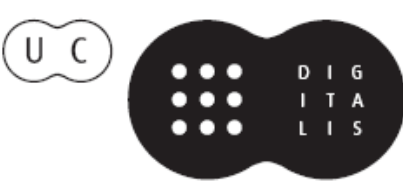




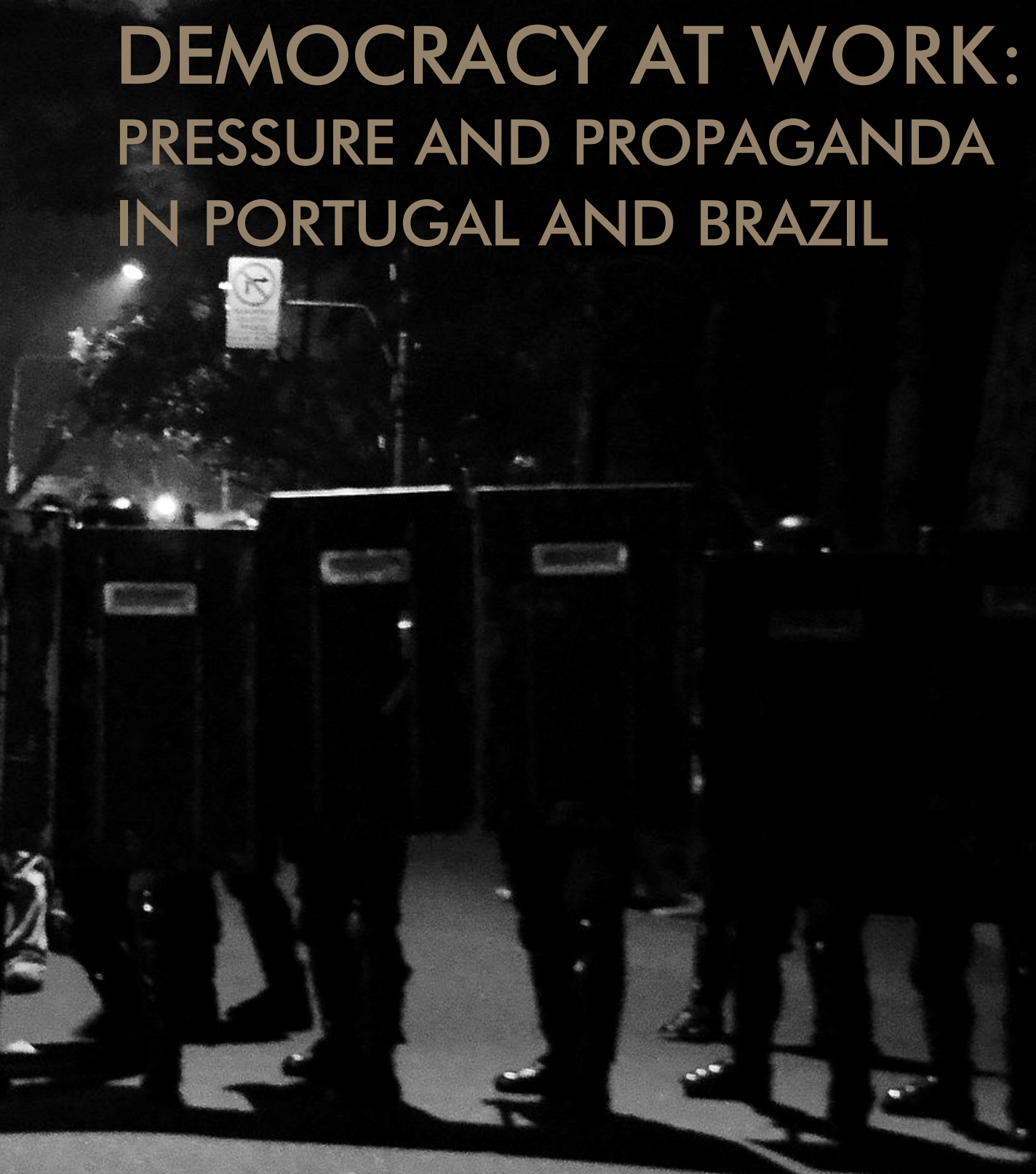

IMPRENSA DA UNIVERSIDADE DE COIMBRA COIMBRA UNIVERSITY PRESS
RITA FIGUEIRAS

PAULA ESPÍRITO SANTO.

ISABEL FERIN CUNHA 


\section{CH A P T E R 3 \\ DEMOCRATIC CULTURE, PUBLICOPINION \\ AND PUNDITRY I N PORTUGAL}

Rita Figueiras

\section{Introduction}

The integration of Portugal in the European Union in 1986 prompted a vast transformation to the country, namely modernization, and political stability (Braga da Cruz 1995). These changes had a huge impact on Portuguese economic structures (higher income rates and a progressive internationalization of the Portuguese economy), employment (socio-professional change, feminization and progressive growth in the tertiary sector), education and qualification of the Portuguese population (particularly amongst young generations and women), democratization of political structures, and liberalization of the media sector (Freire 2003, Cardoso and Costa 2005). Hence, in the aftermanth of both the institutionalization of Portuguese democracy and the development of the media sector in the 1990s, an increased relevance given to public debate started to be noticed, and, with that, the value and visibility given to punditry increased considerably (Figueiras 2005, 2008, 2011).

The valorization of public debate culture can be framed in western societies' cultural matrix, which perceives democracy as a social organization model structured itself around communication and public opinion as the prime mover of democratic politics (Habermas 1984, Fraser 1991, 
2007, Luhmann 1992, Schudson 1995). In several instances within the public sphere, where the media and op-ed pages represent the 'public voice' of the press (Nimmo and Combs 1993, McNair 2003), society debates public issues and public opinion is built.

Jürgen Habermas and Niklas Luhmann are leading scholars whose theories embody opposite archetypes regarding public opinion function in democratic politics. For Habermas (1984), it is through communication that debate takes place in society, and where citizens embody a powerful political role in reinforcing civic culture. Diversity and pluralism of voices, themes and perspectives are considered to be elements that shape the democratic cultural identity model, and that structure the interaction among its main features: political system, media and public opinion. In turn, according to Luhmann, public opinion is a structure formed by institutionalized issues conveyed by the media, but defined according to the political system's needs, that he calls thematization. This concept can be understood as a process of definition, establishment and recognition of major public themes throughout media action (Luhmann 2005: 30-32). Therefore, the author understands public opinion as a consequence of a selective activity by the media that gives relevance to a set of public issues. These themes don't intend to determine either opinion contents or decision or action; they serve, exclusively, to capture attention and to reduce uncertainty according to the political system's strategic decisions.

In Western cultural tradition of the public sphere, diversity and pluralism of voices, themes and perspectives are considered to be structuring democratic cultural values that society esteems. Furthermore, in spite of how differently it may be shaped in democratic politics, epitomized in Habermas and Luhmann's opposite archetypes, public opinion is considered to be the prime mover of democratic politic (Habermas 1984, Fraser 1991, 2007, Luhmann 1992, Schudson 1995), which, in turn, is framed by historical, political, cultural, and media development, as configuring elements of political communication culture (Hallin and Mancini 1996). The chapter departs form this acknowledgement to discuss the 'democraticity' of the Portuguese democratic culture. For that purpose mechanisms that lead to public opinion building will be analyzed, by studying one of its components, published opinion. 


\section{Objectives and Methodology}

In several instances within the public sphere society debates public issues and public opinion is built through tensions, negotiations and consensus. Hence, mediation is a pivotal keyword concerning the structural and cultural identity of democratic regimes. Mediation works as a cultural-political tool for dealing with ongoing, dynamic, fluid, and conflicting processes involving several sets of actors in shaping public debate.

Within this process, pundits play a relevant role (Nimmo and Combs 1994, McNair 2003). Moreover, considering the ripple effect of the pundits' agenda when analyzing public issues. Hence, researching punditry offers relevant insights for understanding Portuguese democracy culture. Within this framework, the chapter will focus on Portuguese punditry and the analysis will be defined and conducted by the aim of discussing the 'democraticity' of the Portuguese democratic culture, which translates into a set of research questions that will be presented further on.

For that purpose four Portuguese mainstream newspapers were selected: daily Diário de Notícias (DN), Público, and weekly Expresso and Visão. These are the agenda-setters of several Portuguese public agendas, mainly in the political sphere and other media. Rather than wishing to emphasize the role of each newspaper, this research aims to uncover the general trends present in the mainstream press, as a constitutive element of public life in Portugal. ${ }^{6}$

The period of analysis of the study comprises the years from 2000 to 2005. This timeframe was established for the analysis because it corre-

\footnotetext{
${ }^{6}$ The research opted for analyzing the mainstream press punditry because, as previous studies have shown (Figueiras, 2005, 2008, 2011), other media pundits, i.e. television, radio, Internet, are traditionally recruited from the press. Since the 1980 s the mainstream press is the place were pundits public credibility and prestige is built and confirmed. The symbolic status that pundits gain in the op-ed pages is an asset recognized by the other media that tend to recruit those already well-known public figures for their own op-ed spaces. One must bear in mind that this sector is rarely renovated, and that it feeds the logic of the star-system, characterized by always searching for and promoting the most recognized and the best media promoted columnists in the public's eye. The pundits who have such visibility are, generically, always the same, accumulating and circulating abundantly through the various commentary spaces: radio, press, digital publications, the blogosphere, and social networking sites. Therefore, in Portugal there is a strong tradition for pundits to be multimedia ones. Hence, by analyzing the mainstream press pundits, generalizations to the Portuguese punditry sphere can be made.
} 
sponds to an historical period in the Portuguese democratic life when it is already possible to state that the Portuguese democratic regime, and within it Portuguese public debate culture, was normalized. Hence, within this timeframe it is possible to understand the Portuguese democratic culture at work in a stabilized context. Taking into account that regularity and continuity are main characteristics of op-ed pages a sample period was built considering January, May and September of each year analyzed, from 2000 to 2005.

The research will be developed within a two-step approach. Firstly, the profile of Portuguese pundits will be researched in order to identify the social fields from which pundits are recruited. A special attention will be given to pundits coming from the political field, namely their party affiliation. A professional biography was built to identify the pundits' profiles, considering the following categories (Mills 1981, Bottomore 1974): Academia (teaching, research); Culture (art related activities); Church (priests); Journalism (journalists); Media (media professionals); Military (army members); Politics (MPs, governments, militants); Liberal Professions /Upper Management (Public or Private institutions).

Considering the relevance the media have in contemporary politics (Meyer 2002), and the fact that the op-ed section is a place of social power that gives status to pundits, legitimacy to their opinions, and a leading role in public opinion building (Nimmo and Combs 1994, McNair 2003), what are the pundits' profiles? Will a diversified and heterogeneous profile to be found? And where are they being recruited? The research hypotheses are that (1) a high level of pundits is recruited in social fields of power, and that (2) a high presence of political pundits is to be found in the op-ed pages.

Secondly, in order to research a little deeper the 'democraticity' of the Portuguese democratic culture, pundits' agenda and the way they discuss national politics will be analyzed. The research starts by identifying pundits' agenda with a special interest in understanding the place political issues have in their agenda. The analysis of the opinion pieces proceeded as follows: first, the coder (the author of the paper), considering the sample period mentioned, provided a running account of the 
topics in each article for identifying the main themes that each op-ed piece conveyed. The result from this preliminary analysis allowed to reconstituting pundits' agenda. ${ }^{7}$

Considering Public sphere cultural matrix which understands it as a place where diversified themes should be discussed (Habermas 1984, Schudson 1995, Fraser 2007), on the one hand, and the relevance political issues have in news media agenda (Patterson, 2001), on the other hand, what are the dominant topics addressed by pundits? What is the relationship between the topics addressed in the op-ed pages and the news media agenda? What is the relevance of political issues in pundits' agenda? The research hypotheses are that (1) punditry agenda is mainly built by the news media agenda, and (2) that it is an agenda that revolves around political issues.

The results from the preliminary analysis of the pundits' agenda also allowed to identify the op-ed pieces related with the theme national politics ${ }^{8}$ which constituted the corpus of analysis of this specific item of the research, making a total of 6870 opinion pieces analyzed. 9 To identify the way pundits discussed national politics, the study employed traditional quantitative content analysis techniques, and three variables were defined: Frame, Style and Tone, sub-divided into a set of indicators.

Frame proposes an interpretative orientation of how pundits debate national politics. Following the theme categories systemized by journalistic coverage patterns of politics, three indicators were built (Graber 2000, Patterson 2001, Siegelmann and Bullock 2000, Brants 2006): issue (public affairs substance); personalization/leadership (politicians' characteristics: professional experience, leadership abilities, character, competence, wisdom, physical appearance); strategy/horse race (tactic and political

\footnotetext{
7 For thematic categorization an inventory of themes was built: National Politics; International Politics; European Union; Social Issues; Economy; Health; Education; Culture; Social Chronicle; Sports; Religion; Justice; Journalism; Terrorism; Others.

${ }^{8}$ For the National Politics theme an inventory of topics was built: Government affairs; Government; Democracy; Political Party; Parliament; Elections; Economy; Journalism; Scandals; Personality characteristics; European Union; President; State.

${ }^{9}$ For this research a database using SPSS (Statistical Package for Social Sciences) software was built for processing all the gathered information.
} 
astuteness, polls); system/political culture (cultural characteristics that frame political practice).

Variable Style defines the structure of arguments throughout opinion articles, which means, the way pundits present their ideas, considering five modalities: analytic-interpretative/explicative (arguments presented in a pedagogical and complex fashion, intertwining context, causes, consequences); critical (questioning decisions or choices); apologetic (defense of a perspective, enhancing its positive items); irony (satirical and sarcastic writing) and critical/ironic (combination of both categories).

Tone allows an understanding of pundits' evaluation of issues, sub-divided into six modalities: clearly negative, mainly negative, balanced, mainly positive and clearly positive.

Giving special attention to pundits coming from politics and journalism, the research also aims to identify how they argue national politics. Considering the op-ed pages cultural expectation of a place which complements information given by the news media (Habermas 1984, Nimmo and Combs 1994, McNair 2003), and where reflection, enlightening arguments, and informed discussions are offered to readers, is the debate happening in the op-ed pages reflexive-oriented (contextualized, informed, pedagogical, and balanced)? And how do journalists and politicians address national politics on their op-ed pages? The research hypotheses are that op-ed pages (1) tend to discuss political issues as contemporary journalism does (conflict-oriented, dramatized, and negative towards politics, Patterson, 2010); and that (2) pundits coming from politics and journalism replicate in the op-ed pages the logic of each one fields.

These empirical results will offer relevant insights for understanding Portuguese democracy culture, which will lead the research to its main purpose, i.e. discussing the 'democraticity' of the Portuguese democratic culture. Empirical results will be debated against democratic cultural understanding of public opinion, epitomized in Habermas and Luhmann's theory on the subject. Will public opinion's main cultural values, epitomized in Habermas' theory, be found in the Portuguese op-ed pages; or will its characteristics may be interpreted as empirical evidence of 
Luhmann's perspective, serving the political system's self-referential closure? Considering pundits' dominant profile and the kind of mediation role pundits play and expected to be found, the research would argue that the Portuguese op-ed pagesindicate exclusionary practices contradicting ideals of inclusion and open debate that culturally defines the public sphere, thus reflecting Luhmann's theory.

The paper will proceed as follows: the first part will present a brief contextualization of Habermas and Luhmann's theory on public opinion - as both represent two opposite theoretical archetypes of democratic communicative culture - and it will also confront their thoughts with others in an effort to enlighten the discussion concerning the formation of public opinion; then, anchored in comprehensive empirical data, the profile of Portuguese pundits, their agenda and the way they discuss national politics, giving special attention to politicians and journalists, will be analyzed. The chapter will conclude by answering the questions that guided the research by framing its findings in the discussed theoretical framework.

\section{Public Opinion and theoretical archetypes of democratic communicative culture}

In western societies' cultural rhetoric, democracy structures itself around communication, and in this social organization model the public sphere occupies a central place (Habermas 1984, Fraser 1991, 2007, Schudson 1995). This conventional meaning underlies the normative understanding of public opinion that became a principle of legitimacy, whose moral and ethical character resides in publicity and in criticism (Habermas 1984, Cornu 1999, Garnham 2000, Keane 1991, McNair 2003). As Fraser states (2007: 7), 'the concept of the public sphere was developed not simply to understand communication flows, but to contribute a normative political theory of democracy. (...). Thus, it matters who participates and on what terms. In addition, a public sphere is conceived as a vehicle for marshaling public opinion as a political force. 
Mobilizing the considered sense of civil society, publicity is supposed to hold officials accountable and to assure that the actions of the state express the will of the citizenry.' Therefore, rationality, and public debate became elements that have shaped the democratic cultural identity model and that structured interaction among its main features: political system, media and public opinion. In so doing, collective compromise started to be valued and built on an idea of proximity between representatives and the represented (Habermas 1984).

This democratic cultural understanding of public opinion that shaped European dominant intellectual tradition is epitomized in what could be called as the habermasean theses. For Habermas (1984), democracy structures itself around communication. In this social organization model the public sphere occupies a central place. Habermas (1984: 68) defines it as 'a symbolic place in mediating civil society and the state', and where citizens embody a powerful political role, through public opinion. According to Habermas, public opinion is considered to be civil society's court of reason, an understanding developed throughout the 18th century. 'In the bourgeois public sphere a developing political awareness started to arise, (...), and through that, civil society learned how to proclaim itself; meaning that public opinion started to be considered as the only legitimized source of laws' (Habermas 1984: 71).

Within this context, public opinion began to have deep political implications. Aiming for public good, society started to build public interest, through publicity and criticism. Publicity, understood as the act of becoming public, became a means to the process of enlightenment; in turn, criticism started to be considered as a pragmatic control mechanism for reaching the best argument during public discussions. In this context, autonomy, diversity and pluralism became public opinion's main cultural values (Habermas 1984: 84).

This conventional meaning became the normative understanding of public opinion that became a principle of legitimacy in democratic regimes (Habermas 1984, Cornu 1999, Garnham 2000, Keane 1991, McNair 2003). Moreover, Luhmann (1992: 66), considers that public opinion has been institutionalized as 'political society's "secret" sovereign and invisible 
authority. (...) And in this semantic shape public opinion has become the main idea of the political system.' However, considering public opinion in the way it was institutionalized during the rise of modern States in the $18^{\text {th }}$ century generates, according to Luhmann, 'an incomprehension of the problem of the concept's inner complexity. What states and concrete operations, what physical and social systems are the sources of this opinion? If this question is raised, the concept's conventional meaning dissolves itself' (Luhmann 1992: 67).

According to the author's rationale, celerity and multiple possible combinations characterize modern societies, and that increments indetermination and social contingency. The growth in social differentiation adds improbability to articulation of interests between systems, increasing, therefore, the improbability of communication.

In this increasing social complexity, the author frames his problematic approach to communication within a thesis of improbability. For Luhmann (1992: 40), '...the main question is (...), how is it possible to establish an order that transforms the impossible into the possible and the improbable into the probable?'. In this sense, if on the one hand communication generates complexity, on the other it makes complexity reduction possible and allows the existence of systems. According to Luhmann, society grows out of an overcoming of impossibility, meaning that improbable, yet not impossible, communication can happen.

Communication, therefore, is perceived as a content selection process that obeys social systems' functional needs. For Luhmann, communication is the central operator of all systems, allowing their existence, operationality, survival and reflectivity (Luhmann 1992, 1998, 2005). Hence, in his perspective, if the $18^{\text {th }}$ century public opinion concept were truly to be applied, it would increase social complexity and the improbability of communication even further. However, 'this doesn't necessarily mean that it should be abandoned, but that it needs to be reconstructed from a radical principle. (...). Only in this way it is possible to take political implications of the concept that is explicable only by its history...' (Luhmann 1992: 67).

Thus, Luhmann suggests a reconfigured concept of public opinion as a structure formed by institutionalized issues, obeying the media's 
relevance according to the political system's needs, that he calls thematization. Public opinion, as simplified communication, can be understood as a process of definition, establishment and recognition of major public themes throughout media action (Luhmann 2005: 30-32). Public opinion as a result of a thematization process allows communication among individuals, requiring their attention only for a limited number of themes. Therefore, public opinion is no longer a consequence of spontaneous discussion on public affairs by civil society in multiple instances, e.g. from television to social networking sites, but of a selective activity by the mainstream media that give relevance to a set of public communication issues. These themes don't intend to determine either opinion contents or decision or action; they serve, exclusively, to capture attention and to reduce uncertainty according to the political system's strategic decisions.

For Luhmann, the true meaning of thematization is to hide within its evidence what really can compromise the political system (1992: 85). In this way, public opinion becomes a sensor, a mirror (as Luhmnann puts it) that reflects political power and its other elements. For Luhmann, it is enough to observe the observers and that excuses the political system from observing the complex environment. In this way, public opinion is considered to be a helping instrument of selective contingency, as a social mechanism for reducing the increase in complexity (Saperas 1993: 91).

Hence, in Luhmann's framework, his disagreement with the 'rational-enlightenment' theories is well emphasized, as is the case in Habermas' thesis and in those inspired by it, which frames dominant European intellectual tradition (Luhmann 1992b, Frasier 2007). For Luhmann, Public opinion as the political system's 'guide-mechanism', its 'poissance invisible' (1992: 83), determines neither political exercise nor opinion formation, but establishes the borders within which the political system is possible. It serves its own self-referential enclosure. Therefore, the political system's legitimacy depends on itself and relies on its own ability to survive, i.e. self-reproductively (autopoiesis).

In the democratic framework society debates public issues and public opinion is built through tensions, negotiations and consensus. Thus, mediation, i.e. 'any acts of intervening, conveying, or reconciling between 
different actors, collectives, or institutions' (Mazzoleni and Schultz 1999: 249), works as a cultural-political tool for dealing with ongoing, dynamic, fluid, and conflicting processes involving several sets of actors in shaping public debate in a cycle of endless mediation. The inherent tension in processes of mediation is a necessary condition for the debate to remain open and continually revised and re-constructed at each of its constitutive levels, which include production, representation, and reception of public debate. Jürgen Habermas and Niklas Luhmann perspectives embody opposite archetypes regarding public opinion mediation in democratic politics, and their perspectives were the guideline for the empirical analysis presented in the following section.

\section{The Portuguese Press Punditry}

Considering punditry as a place of mediation, an instance of reflexivity and of influence, and that opinion genre offers a narrative of and for public life the research regarding Portuguese punditry will follow a two-step approach. Firstly, the profile of Portuguese pundits will be researched; then, pundits' agenda and the way they discuss national politics will be analyzed. In the end, the results will be debated against Habermas and Luhmann's theories.

Pundits profile

Before analyzing what pundits argued about Portuguese politics it is relevant to acknowledge from which place in society they are coming from, and also understand their profile. Between 2000 and 2005, 249 pundits were found, divided into 80 coming from journalism and 169 from other social fields (table 1). Considering the 168 non-journalist pundits, ${ }^{10}$ around $45 \%(\mathrm{~N}=75)$ have or have been involved in a political activity.

\footnotetext{
${ }^{10}$ Regarding one non-journalist pundit, no biographical records were found.
} 
Table 1: Pundits profile (2000-2005)

\begin{tabular}{|l|c|c|}
\hline Pundits & N & $\%$ \\
\hline Journalists & 80 & $32,12 \%$ \\
\hline Non-Journalists & 169 & $67.87 \%$ \\
\hline Total & 249 & $100 \%$ \\
\hline
\end{tabular}

The majority of these columnists has a vast and diverse political curriculum, carrying out top party positions and/or government positions, as well as other activities in other social fields of power, such as Academia, Liberal Professions, namely advocacy and upper-management positions (table 2).

Table 2: Profession of Non-Journalist Pundits

\begin{tabular}{|l|c|}
\hline Profession & $2000-2005$ \\
\hline Culture & 7 \\
\hline Politician & 8 \\
\hline Politician/Culture & 4 \\
\hline Professor & 23 \\
\hline Professor/Culture & 12 \\
\hline Professor/Politician & 18 \\
\hline Professor/Politician/Upper Management & 24 \\
\hline Professor/Upper Management & 17 \\
\hline Upper Management/Liberal Professional & 15 \\
\hline Upper Management/Politician & 21 \\
\hline Media & 5 \\
\hline Others & 11 \\
\hline
\end{tabular}

Considering party affiliation (table 3), the relationship between parliamentary representation and op-ed pages distribution stands out. Firstly, no pundit comes from a non-parliamentary represented party; secondly, the major parties have a highlighted position. The difference between pundits from the Socialist Party (PS) and Social Democratic Party (PSD), and the remaining parties stands out; ${ }^{11}$ thirdly and consequently, bipolarization between power parties on op-ed pages can be observed.

11 Bloco de Esquerda (BE) is an exception. This political party appeared in 1999, and since then has progressively increased its electoral turnouts. These results have a political explanation (electoral discontentment regarding parties of the left, and changing Portuguese values, especially among youth in Freire, Lobo \& Magalhães, 2004). However, BE's communication strategy must not be minimized, especially its non-mainstream and provocative political communication language (verbal, scenic, and performance) and its ability to set the media's agenda. The disparity between the party's longevity, parliamentary representation (fifth force in Parliament) and its visibility is well exemplified by its over-representation in op-ed pages. 
Table 3: Political Party Representation (2000-2005)

\begin{tabular}{|l|c|c|c|c|c|}
\hline Party & BE & CDU & PS & PSD & CDS \\
\hline Pundits & 6 & 3 & 33 & 23 & 11 \\
\hline
\end{tabular}

It seems that op-ed political representation is shaped by political parties, i.e. conventional representation (Freire, Lobo and Magalhães 2004), and is also governmentalized, not only by the prevalence of government parties, but also by a strong presence of elements accumulating opinion columns and public office positions, allowing them the power to decide and the power to comment on their own decisions.

These results confirm the research hypothesis. Regarding the pundits' profile it can be concluded that a high level of pundits is recruited in social fields of power. It is quite clear that pundits are originating from academia, politics and liberal professions. These elements, when combined with the professions of the columnists, reveal that the pundits' sphere, for the most part, is occupied by the elite Portuguese powers (Mills 1981). Thus, one is faced with a conjunction of individuals of elevated status and with both real and symbolic power in Portuguese society, whose presence in the op-ed pages can function in two ways: as a consequence of the status related to the social field of recruitment and as an example of reinforcing 'from the outside in'. It also represents the visibility and conferred status for an opinion column to positively tap into the career of the pundit and his or her originating social field (Bourdieu 1989, Wolton 1994, Luhmann 1995).

In which the presence of politicians in the op-ed pages is concerned, results also confirm the research hypothesis. There is a high presence of politicians in the op-ed pages. Regarding the political party representation, it may be possible to say that the news-value of balance is a criterion employed in the recruitment of political pundits, as the op-ed pages mimic the Portuguese parliament political configuration. Moreover, the over-whelming presence of politicians in detriment of a more diversified and heterogeneous composition of the Portuguese punditry undermines, therefore, its possibility of being an autonomous instance from the political sphere, and also of being a 'symbolic platform' (Wolton, 1995) for diversified social fields to participate in framing public debate. 
Autonomy, diversity of topics and pluralism of opinions are relevant indicators of the democraticity of the public sphere (Habermas 1984, Schudson 1995, Fraser 2007). Hence, characterizing pundits' agenda and debate will allow one to identify the array of topics, perspectives addressed, and opinions argued in the op-ed pages, and thus adding elements to discuss the democraticity of the Portuguese democratic culture.

Regarding pundits' agenda, between 2000 and 2005, in the 6870 articles analyzed, a wide range of themes were debated, such as politics, economics, social issues, judicial issues, sports or religion. At first glance, this variety of subjects could indicate that diversity was guaranteed, but a closer look gives a different perspective.

Table 4: Pundits Agenda - main themes

\begin{tabular}{|l|l|l|}
\hline Themes & N & $\%$ \\
\hline Culture & 543 & $7,90 \%$ \\
\hline International Politics & 672 & $9,78 \%$ \\
\hline National Politics & 3027 & $44,06 \%$ \\
\hline Terrorism - 9/11 & 470 & $6,84 \%$ \\
\hline
\end{tabular}

Table 4 presents the main topics discussed by pundits and as the figures show, national politics was the dominant topic in $42 \%(\mathrm{~N}=3027)$ of the articles, followed by international politics in $10 \%(\mathrm{~N}=672)$ of the columns. The remaining 15 identified themes were dispersed among the other $48 \%$ of the published articles.

As results show, a short list of themes requires people's continuous attention. There are big thematical areas, like national and international politics, filled up with new and routine events that hold a permanent place in the media's agenda, in both news and comment format. Thus, and confirming the research hypothesis, it can be concluded that novelty is a central value for defining pundits' agenda, which revolves around political issues. By and large, pundits discuss topics that are at the top of the media's agenda, and they stop talking about those subjects when they lose novelty, which in contemporary media frenzies is rapidly. This 
tendency means also, that the op-ed pages have difficulty in being an autonomous instance oriented by its own timeframe.

The four main national political topics discussed by pundits (Table 5) represent $57 \%(\mathrm{~N}=3027)$ of the totality of topics on this issue. Concerning government affairs, elections, government and party politics, the majority of these articles were institutionally scoped, which is an angle that interests those related to political power.

Table 5: National Politics main topics (2000-2005)

\begin{tabular}{|l|c|c|}
\hline Topics & $\mathrm{N}$ & $\%$ \\
\hline Government Affairs & 688 & $22,72 \%$ \\
\hline Elections & 498 & $16,45 \%$ \\
\hline Government & 300 & $9,91 \%$ \\
\hline Party Politics & 244 & $8,06 \%$ \\
\hline Total & 3027 & $100 \%$ \\
\hline
\end{tabular}

As already mentioned, journalists occupied a quota of $32 \%(\mathrm{~N}=80)$ in the universe of pundits and politicians represented 30\% ( $\mathrm{N}=75)$ of all punditry. Together, they dominated $62 \%$ of the op-ed pages. The remaining $38 \%$ were from Academia, Culture, the Church, Liberal professions and the media.

Journalists were also the pundits who most frequently discussed national politics in their columns (around 54\% of all written articles on the subject), followed by politicians (23.5\%), centralizing the debate on public affairs between both. 
Journalists and National Politics:

Table 6: Framing

Table 7: Style

Table 8: Tone

\begin{tabular}{|l|c|c|l|c|c|l|c|c|}
\hline Indicators & $\mathrm{N}$ & $\%$ & Indicators & $\mathrm{N}$ & $\%$ & Indicators & $\mathrm{N}$ & $\%$ \\
\hline Issue & 141 & $12,62 \%$ & A-I/E & 261 & $23,36 \%$ & $\mathrm{CN}$ & 624 & $55,86 \%$ \\
\hline P/L & 75 & $6,71 \%$ & Critical & 635 & $56,84 \%$ & $\mathrm{MN}$ & 105 & $9,40 \%$ \\
\hline S-HR & 182 & $16,29 \%$ & Apologetic & 81 & $7,25 \%$ & Balanced & 171 & $15,30 \%$ \\
\hline I-P/L & 90 & $8,05 \%$ & Ironic & 90 & $8,05 \%$ & MP & 40 & $3,58 \%$ \\
\hline I-HR & 269 & $24,08 \%$ & C/I & 48 & $4,29 \%$ & CP & 132 & $11,81 \%$ \\
\hline P/L-HR & 103 & $9,22 \%$ & Not Valid & 2 & 0,99 & Neutral & 40 & $3,58 \%$ \\
\hline I-P/L-HR & 231 & $20,68 \%$ & Total & 1117 & $100 \%$ & Not Valid & 5 & 0,99 \\
\hline S/PC & 5 & $0,44 \%$ & & & & & &
\end{tabular}

\begin{tabular}{|l|c|c|}
\hline Not Valid & 21 & 0,98 \\
\hline Total & 1117 & $100 \%$ \\
\hline
\end{tabular}

Legend Table 6: $\mathrm{P} / \mathrm{L}=$ Personalization/Leadership; S-HR = Strategy-Horse Race; $\mathrm{I}-\mathrm{P} / \mathrm{L}=$ Issue - Personalization/Leadership; I-HR = Issue-Horse Race; P/L-HR = Personalization/Leadership-Horse race; I-P/L-HR = Issue-Personalization/ Leadership-Horse Race; S/PC = System/Political Culture. Table 7: A-I/E = Analytic-Interpretative/Explicative; $\mathrm{C} / \mathrm{I}=$ Critical/Ironic. Table 8: $\mathrm{CL}=$ Clearly Negative; $\mathrm{MN}=$ Mainly Negative $; \mathrm{MP}=$ Mainly Positive $; \mathrm{CP}=$ Clearly Positive;

Considering tables 6 to 8, journalists' debate on national politics was mainly framed (table 6) as "issue/horse racing» $(\mathrm{N}=269,24.08 \%)$; "critically" styled (table 7$)(56.84 \%, \mathrm{~N}=635)$, and the prevalent tone (table 8) was "clearly negative" $(55.86 \%, \mathrm{~N}=624)$. If tones were merged it would be possible to conclude that journalist's evaluation of national politics is really unfavorable $(65.26 \%, \mathrm{~N}=729)$, leaving behind the more "balanced" and "neutral» $(18.88 \%, \mathrm{~N}=211)$ tones, as well as the favorable ones (15.39\%, $\mathrm{N}=172)$.

An opinion article published by Luís Delgado (journalist of DN) in January $10^{\text {th }}, 2000$, illustrates these tendencies by criticizing in a very negative tone the work of the then Minister for Public Works: 'João Cravinho's declarations can only be understood as a weak excuse for having done nothing during the four years that he's been in Government. There isn't a single work, a single decision that has remained in our memory.'

Strategy framing (tactical and political astuteness), critical style and the clearly negative tone that dominated journalists' opinion articles, is also well exemplified in José António Saraiva's (editor of Expresso) article on the Portuguese Prime-Minister at that time, António Guterres, on 
May 12 $2^{\text {th }}$ 2001: 'When all were expecting something novel, a sentence, a different word, Guterres just repeated what everybody already knew. (...). By appearing in the political conference without anything to offer, Guterres not only disappointed everybody, but also didn't give delegates, guests or journalists a single reason to have gone there.'

Politicians and National Politics:

Table 9: Frame Table 10: Style Table 11: Tone

\begin{tabular}{|c|c|c|c|c|c|c|c|c|}
\hline Indicators & $\mathrm{N}$ & $\%$ & Indicators & $\mathrm{N}$ & $\%$ & Indicators & $\mathrm{N}$ & $\%$ \\
\hline Issue & 129 & $18,24 \%$ & A-I/E & 257 & $36,35 \%$ & $\mathrm{CN}$ & 370 & $52,33 \%$ \\
\hline $\mathrm{P} / \mathrm{L}$ & 22 & $3,11 \%$ & Critical & 298 & $42,15 \%$ & MN & 46 & $6,50 \%$ \\
\hline S-HR & 55 & $7,77 \%$ & Apologetic & 98 & $13,86 \%$ & Balanced & 108 & $15,27 \%$ \\
\hline $\mathrm{I}-\mathrm{P} / \mathrm{L}$ & 96 & $13,57 \%$ & Ironic & 30 & $4,24 \%$ & MP & 22 & $3,11 \%$ \\
\hline I-HR & 227 & $32,10 \%$ & $\mathrm{C} / \mathrm{I}$ & 21 & $2,97 \%$ & $\mathrm{CP}$ & 140 & $19,80 \%$ \\
\hline P/L-HR & 32 & $4,52 \%$ & Not Valid & 3 & 0,99 & Neutral & 13 & $1,83 \%$ \\
\hline I-P/L-HR & 132 & $18,67 \%$ & Total & 707 & $100 \%$ & Not Valid & 8 & 0,98 \\
\hline $\mathrm{S} / \mathrm{PC}$ & 0 & $0,00 \%$ & & & & Total & 707 & $100 \%$ \\
\hline Not Valid & 14 & 0,98 & & & & & & \\
\hline Total & 707 & $100 \%$ & & & & & & \\
\hline
\end{tabular}

Legend Table 9: $\mathrm{P} / \mathrm{L}=$ Personalization/Leadership; S-HR = Strategy-Horse Race; $\mathrm{I}-\mathrm{P} / \mathrm{L}=$ Issue - Personalization/Leadership; I-HR = Issue-Horse Race; P/L-HR = Personalization/Leadership-Horse race; I-P/L-HR = Issue-Personalization/ Leadership-Horse Race; S/PC = System/Political Culture. Table 10: A-I/E = Analytic-Interpretative/Explicative; $\mathrm{C} / \mathrm{I}=\mathrm{Critical} /$ Ironic. Table 11: $\mathrm{CL}=$ Clearly Negative; $\mathrm{MN}=$ Mainly Negative $; \mathrm{MP}=$ Mainly Positive; $\mathrm{CP}=$ Clearly Positive;

Tables 9 to 11 show how politicians discussed national politics in their columns. As the figures show, this topic is mainly framed (table 9) as «issue/strategy-horse race» $(32.10 \%, \mathrm{~N}=227)$, followed by «issue» $(18.24 \%$, $\mathrm{N}=129)$; "critically" (42.15\%, N=298) and "analytic-interpretative/explicative" (36.35\%, $\mathrm{N}=257$ ) styled (table 10). Considering the merging of tones (table 11), data show that unfavorable tones $(58.83 \%, \mathrm{~N}=416)$ prevailed over favorable $(22,91 \%, \mathrm{~N}=162)$ and balanced $(15.27 \%, \mathrm{~N}=108)$ ones.

These results show two different positions regarding politicians. On the one hand, they write considering the substance of issues, in an analytical, balanced and favorable way; and, on the other, they write in a very critical, negative and distrustful fashion about national politics, just as journalists do.

The evaluation of how politicians commented on Portuguese politics during the period analyzed allows an understanding of the dual shades of 
their articles. More than evoking two different positions on op-ed pages, it reveals a differentiated strategic approach regarding the object of their commentary. The combative format makes use of accusations, unilateral explanations, presentation of motives and carefully chosen facts. It enhances protest, condemnation, and intransigent opposition in a fight over supporters; and the apologetic format is reserved for their own political interests and for spreading a positive spin over the subjects discussed (Torres, 1988).

These tendencies can be illustrated by the following opinions, which are framed in tactical and political astuteness, critically styled, clearly negative toned, and institutionally scoped, and which take into account the political pundit's political color. Correia de Campos (an MP and Minister of Health in the former PS's Government in 2001-2002) wrote on the Government at the time, headed by Pedro Santana Lopes (from the PSD, and also former pundit in DN, 2001-2003), on October $8^{\text {th, } 2004 \text { in }}$ Público: 'Force is the weapon of the weak. If it were strong, the government would govern, instead of being occupied with the weekly critiques of $\operatorname{MRS}^{12}(\ldots)$. None of this should happen in a State of law.'

The majority of the columnists use op-ed pages to attack their opponents and defend their political and party causes. Politicians' columns have a propagandistic function aiming to lead the public towards strategic directions, through combative or apologetic comments, of which the following are a very clear example.

Medeiros Ferreira (a PS MP, when the party was in power) wrote about the EU Portuguese presidency on January $4^{\text {th }} 2000$ in DN: '...the Portuguese term in office is remarkable. It serves as an example of the political importance of the rotating presidency. (...). This is amply visible in the programme presented by the Portuguese Government.' A week later, Vasco Graça Moura, a PSD European MP, also wrote about the EU Portuguese presidency, but from the leading opposition party's perspective, in January 12, 2000 in DN: '...the Government, besides the usual bla bla bla, hasn't a

12 MRS stands for Marcelo Rebelo de Sousa. He is a very reputed Portuguese pundit, Academic, Jurist, and Politician (former leader of PSD, Minister, and MP). 
single consistent idea to articulate the defense of our interests regarding the EU presidency (...). This Government isn't ready to exist in Europe.'

From these research results it can also be concluded that there were almost no figures framed as «system/political culture». This frame contextualizes subjects according to political and social values that frame Portuguese society, and the absence of this perspective reflects a scant civic pedagogic component in op-ed pages. Consequently, citizens' involvement in public affairs is scarcely present in pundits' articles. Adding to that the institutional scopes prevalent in op-ed pages, it can be concluded that shaping the debate around institutional politics circumscribes discussion within the political system and excludes citizens as a counterpart in public debate.

These findings stimulate also a reflection regarding the way journalists and politicians write about national politics, how they position themselves in the op-ed section, and symbolic benefits that they seem to get from it, particularly regarding each other.

Literature on the relationship between journalism and politics (Patterson 2001, McNair 2003, Brants 2006, Graber, McQuail and Norris 2008) offer insight into this reflection. Scholars state that journalistic coverage of the political system is mainly critical, negative and strategy-horse race oriented. In recent decades, this coverage pattern has been institutionalized as an aftermath of the political system's orientation towards the media. 'Media-shaped politics' (Meyer 2002) is ready to be publicized without editing; but to spin doctors' propagandistic strategy, journalists answer back by covering politics in a critical, negative and distrustful fashion.

This adversarial position, more than revealing political disagreement, aims to reflect journalistic autonomy (in what Luhmann would call a system differentiation move), whose identity matrix was built, roughly at the same time, as an authoritarian political opponent and as political watchdog and representative of public opinion(Keane 1991, Champagne 1998, Cornu 1999, Norris 2010). And as Pierre Bourdieu says (1989: 69): 'understanding a field's social genesis and grasping the creed of the specific need that sustains it, the language game that is played in it, the material and symbolic things at stake in it, is explaining (...) the acts of producers and the work they produce...' 
From the empirical evidence of this research it can be concluded that journalists' opinion articles are similar to their political coverage, reflecting what could be called journalists' 'anti-political class culture'. Empirical data suggest also that politicians use op-ed pages to attack their opponents and defend their political and party causes. Hence, politicians seem to look at op-ed pages as an extension of Parliament and journalists as an extension of the newsroom, thus confirming the research hypothesis. Therefore, op-ed pages may be perceived as a place for power struggle between journalists and politicians, where their social legitimacy as the representative of public opinion, shaped by each one's own identity and their relationship, is at stake.

While politicians have a formal legitimacy, journalists have a self-proclaimed one, built on their ethical and deontological professional values that allow them, in the name of public opinion, to check the political system's conduct (Cornu 1999, Norris 2000). However, in spite of the fact that the political system maintains high formal legitimacy, it is increasingly being questioned, which puts it at risk as society's reference-system (Luhmann 1992). In turn, the media's socio-political relevance in contemporary societies is giving them increasing power for constructing reality (Bourdieu 1989; Luhmann 2005). Thus, in contemporary societies, journalists and politicians struggle over definitions of news, politicians' control of their image, political interpretation of polls, and, as this research indicates, they also struggle over public debate control. In this way, published opinion can be seen as a privileged place for struggle over meaning, as a strategy for power affirmation by politicians, but, as this research seems to attest, that may be extended to journalists as well.

\section{Conclusion}

This chapter aimed at researching mechanisms that lead to public opinion building, by studying one of its components, published opinion in Portugal. For that purpose, the profile of pundits, their agenda and the way they discuss public affairs were analyzed. 
Furthermore, by researching punditry the chapter aimed to debate the 'democraticity' of the Portuguese democratic culture.

Despite the fact that in western cultural identity of the public sphere, diversity and pluralism of voices, themes and perspectives are considered to be structuring democratic cultural values that society esteems, the empirical results of this study indicate exclusionary practices contradicting ideals of inclusion and open debate. Thus, the article would argue that, instead of promoting and reinforcing democratic culture, epitomized in habermasean theses, punditry may be interpreted as empirical evidence of Luhmann's perspective on public opinion serving, preferentially, the political system's self-referential closure.

This statement may be materialized, firstly, by the high presence of pundits coming from politics. Secondly, by political pundits' profiles, namely the reduction of complexity by centralizing the debate in the two dominant Portuguese political parties, the PS and the PSD - which have alternate government hold -, allowing them to participate directly in constructing and structuring public attention around a limited set of big issues, while fragmented in a vast variety of topics requiring short-term attention span, as illustrated by pundits' agenda. And, thirdly, by the fact that politics was discussed from the political system's point of view, as sub-section concerning journalists and politicians writings have indicated.

At a first glance, journalists' opinion pieces, together with their political news coverage, seem to express a menace to the political system's symbolic survival. However, considering the terms in which discussion takes place in op-ed pages, journalistic menace to the political system may be more apparent than real.

Discontinuity, conflict, personalization, novelty and recurrence (Luhmann 2005: 57-68) are forms set on binary distinctions that, as findings suggest, structure polemics that feed op-ed pages. Adding to this, celerity by which themes continuously succeed them reinforces the idea of published opinion as thematic structure immerging in a political communication process that, instead of jeopardizing political system, serves its contingent interests. Temporal rhythmization gives continuity to the 'need for discontinuity' (Luhmann 1992: 79), meaning that op-ed pages may be characterized by 
their 'ability to aggregate and disaggregate the environment and to use that to primordially assure continuity of a specific type of communication' (Luhmann 1992: 75), neutralizing, therefore, any potential threat.

Hence, at the same time that public opinion - and in the case considered, published opinion as well - allows the political system to manage individuals' attention span, public opinion also functions as one of its most important sensors, whose observation substitutes direct observation of the complex environment - impossible by definition, according to Luhmann - in a mirror that reflects the political system components, simultaneously observed and observers that act in front of the mirror: 'other people, groups, political parties and versions of the same subject' (Luhmann 1992: 86), such as journalists and their opinion writings.

Overall, it seems to be possible to suggest that the Portuguese democratic culture promotes exclusionary practices contradicting ideals of inclusion and open debate. It may be argued that published opinion serves less to establish external contacts, than to allow self-observation and the necessary reflectivity to maintain the political system's self-referential closure. ${ }^{13}$ Therefore, if in the traditional cultural identity of the public sphere, of which op-ed pages are one instance, diversity and pluralism of voices, themes and perspectives are considered to be structuring values that society esteems and that allow the building of enlightened public opinion; the empirical results discussed in this chapter, however, indicate that 'there is nothing that guarantees the possibility of achieving real agreements, but there is a public communication that supports itself in this fiction and that assures its continuity' (Luhmann1992: 73).

\section{References}

Bottomore, T. B. (1964) Elites and Society. London: Routledge.

Bourdieu, P. (1989) O Poder Simbólico/Language and symbolic power. Lisboa: Difel.

13 Against the background of Luhmann's theory, it would be interesting to analyze the recent riots in Greece, and the 'M-15' movement in Spain, as countermove acts against the Southern European political system modus operandi, which are making citizens feel excluded from political debate and the decision making process. 
Brants, K. (2006) 'The Good, the bad and thecynical political journalism under attack' in $2^{\text {nd }}$ International Conference on journalism and democracy. Lisboa: CIMJ.

Champagne, P (1990) Faire l'opinion/Opinion making. Paris: Éditions de Minuit.

Cornu, D. (1999) Jornalismo e Verdade/Journalism and truth. Lisboa: Instituto Piaget.

Cunha, I. (2007) 'Fins de mandato de primeiros-ministros: Tendências de cobertura/PrimeMinisters end of mandate: news coverage trends' in I. Cunha (ed.) Jornalismo e democracial Journalism and democracy. Lisboa: Paulus.

Figueiras, R. (2005) Os Comentadores e os Medi/ The Pundits and the Media. Lisbon: Livros Horizonte Publishers.

Figueiras, R. (2009) O Comentário Político e a Política do Comentário/The Political Pundits and the Politics of Punditry. Lisbon: Paulus Publishers/Portugal-Brasil.

Figueiras, R. (2011) 'Press Pundits and Portuguese Society' in Journalism: Theory, Practice, and Criticism, vol. 12(3): 317-333.

Fraser, N. (1991) 'Rethinking the public sphere: A contribution to the critique of actually existing democracy'in C. Calhoun (ed.) Habermas and the public sphere. Cambridge: MIT Press.

Fraser, N. (2007) 'Transnationalizing the public sphere. On the legitimacy and efficacy of public opinion in a post-westphalian world' in Theory, Culture E Society, 4(4): 7-30.

Freire, A., Lobo, M.C. and Magalhães, P. (eds.) (2004) Portugal a votos/Portugal voting. Lisboa: ICS.

Garnham, N. (2000) Emancipation, the media and modernity, Oxford: Oxford University Press.

Graber, D., McQuail, D., Norris, P. (2008) The Politics of News The News of Politics, New

York: C Q. Press. Habermas, J. (1984) Mudança estrutural da esfera pública/The structural transformation of the public sphere. Rio de Janeiro: Tempo Brasileiro.

Hallin, D. and Mancini, P. (2004) Comparing Media Systems: Three Models of Media and Politics. Cambridge: Cambridge University Press.

Keane, J. (1991) The Media and Democracy. Cambridge: Polity Press.

Luhmann, N. (1992) A improbabilidade da comunicação/The improbability of communication. Lisboa: Vega.

Luhmann, N. (1994) An interview in Theory, Culture \& Society, 11(2): 37-69.

Luhmann, N. (1995) Poder/Power. Barcelona: Editorial Anthropos.

Luhmann, N. (1998) Observations on Modernity. Stanford: Stanford University Press.

Luhmann, N. (2002) 'What is communication?' in W. Rasch (ed.) Theories of distinction: Redescribing the descriptions of modernity, Stanford: Stanford University Press.

Luhmann, N. (2004) Law as a Social System. Oxford: Oxford University Press.

Luhmann, N. (2005) A realidade dos meios de comunicação/The reality of the mass media. São Paulo: Paulus.

McNair, B. (2003) An introduction to political communication. London: Routledge.

Nimmo, D. and Combs, J. E. (1992) The political pundits. New York: Praeger.

Norris, P (ed.) (2010) Public Sentinel: News Media \& Governance Reform. Washington DC: The World Bank.

Patterson, T. (2001) 'Are news media effective political actors?' in Political Communication, 14(4): 445-455. 
Saperas, E. (1993) Os efeitos cognitivos da comunicação de massas/Mass communication cognitive effects. Porto: Asa.

Sartori, G. (2000) Homo videns.Televisão e pós-pensamento/Homo videns. Television and post-thought. Lisboa: Terramar.

Schudson, M. (1995) 'A esfera pública e os seus problemas. Reintroduzir a questão do estado'/Public sphere and its problems: Bringing the State (back) in Comunicação $e$ Linguagens, 21/22: 149-166.

Siegelmann, L. and Bullock, D. (1991) 'Candidates, issues horse races, and hoopla: presidential campaign coverage, 1888-1988' in American Politics Research, 19(1): 5-32.

Wright Mills, C. (1956) The Power Elite. Oxford: Oxford Press. 